Uniwersytet Mikołaja Kopernika w Toruniu

Katedra Ekonometrii i Statystyki

Marek Zarębski

\title{
ROLA EUROPEJSKIEGO FUNDUSZU SPOŁECZNEGO W ROZWOJU ZASOBÓW LUDZKICH
}

Z a rys treści. Europejski Fundusz Społeczny (EFS), powołany do życia na podstawie artykułu 23 Traktatu o EWG z 1957 roku, został utworzony jako pierwszy fundusz strukturalny Wspólnot Europejskich. Działania Funduszu, nastawione na kreowanie mechanizmów wspierających rozwój rynku pracy, w istotny sposób wspierają realizację Europejskiej Strategii Zatrudnienia. W artykule podjęto próbę określenia roli EFS jako instrumentu wspierającego rozwój kapitału ludzkiego w Polsce. Zaprezentowano obszary wsparcia, programy i właściwe im priorytety EFS. Zaprezentowano również dane empiryczne dotyczące podziału środków dla realizowanego w ramach Funduszu Programu Operacyjnego Kapitał Ludzki w podziale na priorytety i źródła finansowania w latach 2007-2013.

S ł o w a kluc z o w e : Europejski Fundusz Społeczny, Europejska Strategia Zatrudnienia, kapitał ludzki, rozwój zasobów ludzkich.

\section{WSTĘP}

Wejście Polski do UE oznacza nową jakość zarówno w obszarze ekonomii, jak i funkcjonowania społecznego. Wtłacza gospodarkę w odmienny nurt funkcjonowania, sytuuje w ostrzejszej niż dotąd konkurencji, tworzy wymóg poszukiwania konkurencyjnych przewag. Dziś każdy niemal ekonomista podkreśla rolę aktywów niematerialnych, kapitału intelektualnego i jego części kapitału społecznego w tworzeniu warunków zrównoważonego wzrostu gospodarczego. Kapitał ucieleśniony w ludziach, rozumiany w ujęciu społecznym jako stwarzający 
możliwości tworzenia coraz doskonalszych przestrzeni cywilizacyjnych, opartych na więzach społecznych, na wartościach związanych z poczuciem przydatności dla innych ludzi, przynależności do grup, czy też tworzenia nowych wartości, w ujęciu ekonomicznym zaś jako kompleks składający się z wiedzy i umiejętności, zdrowia i energii witalnej, kultury i tradycji, jest podstawową determinantą tego wzrostu.

Jako pełnoprawny członek Wspólnoty Polska stała się jednym z beneficjentów pomocy świadczonej w ramach polityki strukturalnej UE przy wykorzystaniu funduszy strukturalnych. Pomoc ta ukierunkowana na osiągnięcie spójności społeczno-gospodarczej i terytorialnej stanowi istotny wkład w proces kształtowania i rozwoju kapitału ludzkiego.

\section{EFS - EWOLUCJA KONCEPCJI}

Europejski Fundusz Społeczny (EFS) został utworzony jako pierwszy fundusz strukturalny Wspólnot Europejskich. Został powołany do życia na podstawie artykułu 23 Traktatu o EWG z 1957 roku, mimo że stosowne regulacje, dotyczące konieczności jego powstania, pojawiły się o wiele wcześniej.

Już w Traktacie powołującym Europejską Wspólnotę Węgla i Stali (EWWiS) z 18 kwietnia 1951 roku pojawił się zapis o potrzebie utworzenia funduszu wspólnotowego, który miałby za zadanie przyczynienie się do poprawy sytuacji zatrudnieniowej na obszarze Wspólnoty Europejskiej oraz do podniesienia stopy życiowej pracowników. Zgodnie z postanowieniami traktatu EWWiS, podczas konferencji w Messynie w 1955 roku podjęto ostateczną decyzję o powołaniu EFS, którego podstawowym zadaniem byłoby wspieranie mobilności pracowników na obszarze Wspólnoty, zapewniłby on szkolenie i dokształcanie pracowników oraz przyczyniłby się do polepszenia warunków życia obywateli Wspólnoty. Ostateczną decyzję o powołaniu Europejskiego Funduszu Społecznego podjęto w Rzymie w 1957 roku (Grewiński, Malinowski, 2003). Począwszy od lat sześćdziesiątych, EFS ewoluował wielokrotnie, dostosowując się do zmian w polityce spójności społeczno-gospodarczej oraz szeroko rozumianej polityce społecznej UE dotyczącej głównie zatrudnienia (Grewiński, 2003).

Działanie Funduszu od początku nastawione było na kreowanie mechanizmów wspierających rozwój rynku pracy. Pierwotną ideą EFS było wspieranie narodowych polityk rynku pracy. Na bazie kolejnych reform działania EFS zaczęły wpisywać się w cele ponadnarodowe (Kubisz, 2001). W dużej mierze taka rola funduszu była konsekwencją utworzenia w roku 1975 Europejskiego Funduszu Rozwoju Regionalnego (EFRR), który przejął zadania związane ze wspieraniem regionów zacofanych gospodarczo (Auleytner, 1997). EFS nie 
zrezygnował jednak ze wspierania rozwoju regionalnego, a wręcz przeciwnie, począwszy od 1978 roku, włączał się wielokrotnie w pomoc strukturalną dla regionów i w zwalczanie różnic między bogatymi a biednymi obszarami UE (Grewiński, Malinowski, 2003).

Szczególnie ważna dla funkcjonowania EFS była reforma z 1988 r. Włączała ona EFS w całościową koncepcję polityki strukturalnej UE, a więc w ścisłą współpracę z pozostałymi funduszami strukturalnymi Wspólnoty (Europejskim Funduszem Rozwoju Regionalnego (EFRR) i Europejskim Funduszem Orientacji i Gwarancji Rolnej (EFOiGR)).

Lata 2000-2006 to nowy okres działalności EFS. Cały jego potencjał uległ połączeniu na poziomie wszystkich państw członkowskich w celu wdrożenia priorytetów Europejskiej Strategii Zatrudnienia ${ }^{1}$. Podstawowymi filarami tej ostatniej stały się: poprawa możliwości zatrudnienia, rozwój przedsiębiorczości, poprawa zdolności adaptacyjnej przedsiębiorstw i ich pracowników, promocja równości szans. EFS ma wspierać państwa członkowskie Unii Europejskiej w zakresie wprowadzania nowoczesnej, aktywnej polityki zatrudnienia oraz systemów mających na celu zapewnienie wsparcia finansowego dla podnoszenia kwalifikacji zawodowych pracowników (Sobotka, 2001).

Zgodnie z Rozporządzeniem 1784/1999/WE Parlamentu Europejskiego i Rady Europy z dnia 12 lipca 1999 r. „fundusz winien wspierać działania zorientowane na zapobieganie i przeciwdziałanie bezrobociu oraz na rozwijanie potencjału kadrowego i integrację społeczną rynku pracy, w celu promocji wzrostu poziomu zatrudnienia, równości szans mężczyzn i kobiet, harmonijnego i trwałego rozwoju oraz spójności ekonomicznej i społecznej. Fundusz winien w szczególności wspierać działania podejmowane w ramach realizacji Europejskiej Strategii Zatrudnienia”.

Tak więc EFS jest podstawowym narzędziem polityki strukturalnej Unii Europejskiej, które ma służyć realizacji polityki zatrudnienia i rozwojowi zasobów ludzkich.

1 W roku 1993 Rada Europy przyjęła dziesięć podstawowych priorytetowych działań w dziedzinie zatrudnienia: aktywne i prewencyjne działania na rzecz bezrobotnych i biernych zawodowo, tworzenie miejsc pracy i wspieranie przedsiębiorczości, wzmacnianie rozwoju kapitału ludzkiego oraz kształcenia ustawicznego, zwiększanie zasobów pracy i promowanie pozostawania na rynku pracy osób starszych, równość płci na rynku pracy, wzmacnianie integracji i zwalczanie dyskryminacji osób będących w niekorzystnej sytuacji na rynku pracy, rozwijanie finansowych zachęt do podejmowania zatrudnienia, ograniczanie szarej strefy w zatrudnieniu, zwalczanie regionalnych dysproporcji w zatrudnieniu. 


\section{OBSZARY WSPARCIA}

W latach 2000-2006 EFS skupiał się na pięciu obszarach wsparcia:

- aktywne formy walki z bezrobociem w tym:

- zwalczanie bezrobocia młodzieży,

- zwalczanie bezrobocia długoterminowego,

- wspieranie osób zagrożonych bezrobociem,

- wspieranie osób powracających na rynek pracy,

- ułatwianie powrotu na rynek pracy,

- przeciwdziałanie wykluczeniu społecznemu,

- rozwój powszechnego kształcenia ustawicznego²,

- ukierunkowanie systemów kształcenia na potrzeby rynku pracy,

- rozwój sieci kształcenia, lokalnych ośrodków szkoleniowych,

- dostosowanie siły roboczej do zmieniających się potrzeb rynkowych,

- permanentne szkolenia, kursy, doskonalenie się, wzmacnianie mobilności i elastyczności zawodowej,

- wzmacnianie powiązań między instytucjami oświaty i kształcenia a rynkami pracy,

- doskonalenie kadr gospodarki oraz rozwój przedsiębiorczości,

- promowanie wysoko kwalifikowanych i wyszkolonych kadr, m.in.:

- wsparcie dla przedsiębiorczości,

- wspieranie inicjatyw oddolnych,

- wspieranie rozpoczynających działalność gospodarcza,

- rozwój wiedzy i dostępu w zakresie informatyki, telekomunikacji, przekazywania informacji,

- aktywizacja zawodowa kobiet (Grewiński, 2006).

2 Mieszczące się w ramach celu trzeciego działania mają za zadanie przyczynić się do prowadzenia przez państwo takiej polityki kształcenia ustawicznego, która sprzyjałaby pozyskaniu wiedzy i umiejętności, niezbędnych do zmieniających się warunków i wymagań w sferze zatrudnienia, zdecydowanie szerszej grupie osób. Wskazywano na potrzebę tworzenia takich systemów kształcenia, które doprowadziłyby do rozwoju wykwalifikowanej siły roboczej, która nadążałaby za zmieniającą się sytuacją na rynku pracy w Unii Europejskiej. W związku z tym należy wypracować ponadnarodowy system uznawania świadectw i kwalifikacji zawodowych, co automatycznie zwiększy mobilność pracowników w obrębie Unii Europejskiej. Konieczne jest również stopniowe eliminowanie braków w edukacji młodych osób, poprzez podniesienie poziomu krajowych systemów edukacji i oświaty. Ten priorytet w krajach Wspólnoty realizowany jest za pomoca programów w ramach systemu edukacji szkolnej i w ścisłym powiązaniu go z potrzebami rynku pracy. 
Aby realizować wszystkie te obszary polityki zatrudnienia, fundusz musi za każdym razem brać pod uwagę dwa kluczowe cele, które wynikają z tzw. tematów przekrojowych Komisji Europejskiej:

- wspieranie lokalnych inicjatyw w dziedzinie zatrudnienia, a zwłaszcza inicjatyw wspierających lokalne i terytorialne porozumienia na rzecz zatrudnienia,

- możliwości, jakie niesie ze sobą społeczeństwo informacyjne, zarówno w aspekcie społecznym, jak i rynku pracy, gwarantując jednocześnie dostępność do wszystkich udogodnień.

\section{PROGRAMY OPERACYJNE REALIZOWANE W POLSCE ZA POMOCA EFS}

W latach 2004-2006 z EFS realizowane były w Polsce dwa programy operacyjne:

- Sektorowy Program Operacyjny Rozwój Zasobów Ludzkich (SPO RZL),

- Zintegrowany Program Operacyjny Rozwoju Regionalnego (ZPORR).

Priorytety Sektorowego Programu Rozwoju Zasobów Ludzkich odzwierciedlają założenia polityki społecznej i edukacyjnej rządu oraz polityki Unii Europejskiej.

Celem Zintegrowanego Programu Operacyjnego Rozwoju Regionalnego jest tworzenie warunków wzrostu konkurencyjności regionów oraz przeciwdziałanie marginalizacji niektórych obszarów w sposób sprzyjający długofalowemu rozwojowi gospodarczemu kraju, jego spójności ekonomicznej, społecznej i terytorialnej oraz integracji z UE.

Wzmacnianie polityki równych szans w ramach ZPORR należy rozumieć jako uwzględnianie w procesie realizacji poszczególnych projektów interesów grup społecznych znajdujących się w trudniejszej sytuacji: osób niepełnosprawnych, kobiet, osób zagrożonych wykluczeniem społecznym, korzystających ze świadczeń pomocy społecznej, np. długotrwale bezrobotnych i innych.

Rozwojowi zasobów ludzkich w ramach tego programu mają służyć działania w ramach priorytetu drugiego (tabela 1).

Główny cel SPO RZL, tj. poprawa zdolności do uzyskania i utrzymania zatrudnienia poprzez rozwój jakości zasobów ludzkich, miał być osiagnięty poprzez działania, mające poprawić zdolności do bycia zatrudnionym przez osoby poszukujące pracy. Działania w tym zakresie koncentrowały się w szczególności na polepszeniu dostępności i jakości usług oferowanych przez instytucje rynku pracy, podnoszeniu kwalifikacji zawodowych i dostosowywaniu ich do potrzeb 
rynku pracy, planowaniu rozwoju indywidualnego, zawodowego i społecznego oraz nabyciu przez osoby umiejętności właściwego zachowywania się na rynku pracy. Poprawa jakości zasobów ludzkich, która wpływa na wzrost zdolności do zatrudnienia, dotyczy w równym stopniu osób młodych, dopiero wchodzących na rynek pracy, jak i osób dorosłych, które powinny aktualizować posiadane przez siebie kwalifikacje zawodowe. Obie te grupy wymagają stosowania odrębnych, często zindywidualizowanych metod oddziaływania, stąd konieczność odrębnego określenia projektów, które wpływać będą na podwyższanie zdolności do zatrudnienia tych grup społecznych.

Priorytety i działania wspierane przy udziale EFS w ramach ZPORR i SPO RZL w Polsce prezentuje tabela 1.

Tabela 1. Priorytety i działania wspierane przy udziale EFS w ramach ZPORR i SPO RZL w Polsce w latach 2004-2006

\begin{tabular}{|c|c|c|}
\hline Nazwa programu & Nazwa priorytetu & Nazwa działania \\
\hline \multirow[t]{2}{*}{$\begin{array}{l}\text { Sektorowy Program } \\
\text { Operacyjny Rozwój } \\
\text { Zasobów Ludzkich }\end{array}$} & $\begin{array}{l}\text { Priorytet } 1 \\
\text { „Aktywna polityka } \\
\text { rynku pracy } \\
\text { oraz integracji } \\
\text { zawodowej } \\
\text { i społecznej” }\end{array}$ & $\begin{array}{l}\text { 1.1. Rozwój i modernizacja instrumentów i instytucji rynku pracy } \\
\text { 1.2. Perspektywy dla młodzieży } \\
\text { 1.3. Przeciwdziałanie i zwalczanie długotrwałego bezrobocia } \\
\text { 1.4. Integracja zawodowa i społeczna osób niepełnosprawnych } \\
\text { 1.5. Promocja aktywnej polityki społecznej poprzez wsparcie } \\
\text { grup szczególnego ryzyka } \\
\text { 1.6. Integracja i reintegracja zawodowa kobiet }\end{array}$ \\
\hline & $\begin{array}{l}\text { Priorytet } 2 \\
\text { „Rozwój } \\
\text { społeczeństwa } \\
\text { opartego na } \\
\text { wiedzy" }\end{array}$ & $\begin{array}{l}\text { 2.1. Zwiększenie dostępu do edukacji - kształcenie przez całe } \\
\text { życie } \\
\text { 2.2. Podniesienie jakości edukacji w odniesieniu do potrzeb } \\
\text { rynku pracy } \\
\text { 2.3. Rozwój kadr nowoczesnej gospodarki i przedsiębiorczości } \\
\text { 2.4. Wsparcie zdolności administracyjnych }\end{array}$ \\
\hline $\begin{array}{l}\text { Zintegrowany } \\
\text { Program Rozwoju } \\
\text { Regionalnego }\end{array}$ & $\begin{array}{l}\text { Priorytet } 2 \\
\text { „Wzmocnienie } \\
\text { rozwoju zasobów } \\
\text { ludzkich } \\
\text { w regionach" }\end{array}$ & $\begin{array}{l}\text { 2.1. Rozwój umiejętności powiązanych z potrzebami } \\
\text { regionalnego rynku pracy i możliwościami kształcenia } \\
\text { ustawicznego w regionie } \\
\text { 2.2. Wyrównywanie szans edukacyjnych poprzez programy } \\
\text { stypendialne } \\
\text { 2.3. Reorientacja zawodowa osób odchodzących z rolnictwa } \\
\text { 2.4. Reorientacja zawodowa osób dotkniętych procesami } \\
\quad \text { restrukturyzacyjnymi } \\
\text { 2.5. Promocja przedsiębiorczości } \\
\text { 2.6. Regionalne strategie innowacyjne i transfer wiedzy }\end{array}$ \\
\hline
\end{tabular}

Źródło: opracowanie własne.

Całość interwencji EFS w Polsce na lata 2007-2013 realizowana będzie w ramach Programu Operacyjnego Kapitał Ludzki (PO KL) Jest on jednym z podstawowych programów operacyjnych służących realizacji Narodowych Strategicznych Ram Odniesienia (NSRO). 
Celem programu jest umożliwienie wykorzystania pełnego potencjału zasobów ludzkich poprzez wzrost zatrudnienia i potencjału adaptacyjnego przedsiębiorstw i pracowników, podniesienie poziomu wykształcenia społeczeństwa, zmniejszenie obszarów wykluczenia społecznego oraz wsparcie budowy struktur administracyjnych państwa. Program koncentruje się na następujących obszarach wsparcia: zatrudnienie, edukacja, integracja społeczna, rozwój potencjału adaptacyjnego pracowników i przedsiębiorstw, rozwój zasobów ludzkich na terenach wiejskich, budowa sprawnej administracji publicznej wszystkich szczebli, promocja zdrowia. Cele priorytetowe i szczegółowe PO KL prezentuje tabela 2.

Całość kwoty przeznaczona na realizację PO KL wynosi 11429 mln euro. Wkład w ten program EFS wynosi 9707 mln euro, w tym wkład krajowy 1713 mln euro. Udział środków krajowych ustalony został na minimalnym poziomie $15 \%$. W związku z faktem, iż w NSRO Polska zadeklarowała wydatkowanie $60 \%$

Tabela 2. Cele priorytetowe i szczegółowe PO KL w Polsce (ze szczególnym uwzględnieniem celów bezpośrednio związanych z rozwojem zasobów pracy)

\begin{tabular}{|c|c|c|}
\hline \multirow{2}{*}{$\frac{\grave{\Phi}}{\frac{\grave{z}}{z}}$} & Cele priorytetowe & Cele szczegółowe* \\
\hline & \multicolumn{2}{|r|}{ komponent centralny } \\
\hline 1 & $\begin{array}{l}\text { Zatrudnienie } \\
\text { i integracja społeczna }\end{array}$ & $\begin{array}{l}\text { - zwiększenie zasięgu oddziaływania Aktywnej Polityki Rynku Pracy } \\
\text { - wzmocnienie instytucji pomocy społecznej i budowa partnerstwa na rzecz } \\
\text { integracji społecznej }\end{array}$ \\
\hline 2 & $\begin{array}{l}\text { Rozwój zasobów } \\
\text { ludzkich i potencjału } \\
\text { adaptacyjnego } \\
\text { przedsiębiorstw } \\
\text { oraz poprawa } \\
\text { stanu zdrowia osób } \\
\text { pracujących }\end{array}$ & $\begin{array}{l}\text { - rozwój i poprawa funkcjonowania systemowego wsparcia adaptacyjności } \\
\text { pracowników i przedsiębiorstw } \\
\text { - rozwój wykwalifikowanej i zdolnej do adaptacji siły roboczej, poprawa } \\
\text { stanu zdrowia osób pracujących poprzez opracowanie programów } \\
\text { wspierających powrót do pracy } \\
\text { - podnoszenie kwalifikacji i umiejętności personelu medycznego }\end{array}$ \\
\hline 3 & $\begin{array}{l}\text { Wysoka jakość } \\
\text { systemu oświaty }\end{array}$ & $\begin{array}{l}\text { - wzmocnienie zdolności systemu edukacyjnego w zakresie monitoringu, } \\
\text { ewaluacji i badań edukacyjnych oraz ich wykorzystanie w polityce } \\
\text { edukacyjnej i zarządzaniu oświatą } \\
\text { - podniesienie jakości systemu kształcenia i doskonalenia nauczycieli } \\
\text { - poprawa stopnia powiązania oferty w zakresie kształcenia i szkolenia } \\
\text { z potrzebami rynku pracy } \\
\text { - opracowanie i wdrożenie Krajowych Ram Kwalifikacji i Krajowego } \\
\text { Systemu Kwalifikacji oraz upowszechnienie uczenia się przez całe życie }\end{array}$ \\
\hline 4 & Szkolnictwo wyższe & $\begin{array}{l}\text { - dostosowanie kształcenia na poziomie wyższym do potrzeb gospodarki } \\
\text { i rynku pracy } \\
\text { - poprawa jakości oferty edukacyjnej szkół wyższych, podniesienie } \\
\text { atrakcyjności kształcenia w obszarze nauk matematyczno-przyrodniczych } \\
\text { i technicznych na poziomie wyższym } \\
\text { - podniesienie kwalifikacji kadr sektora B + R }\end{array}$ \\
\hline 5 & Dobre rządzenie & \\
\hline
\end{tabular}


Ciąg dalszy tabeli 2

\begin{tabular}{|c|c|c|}
\hline \multirow{2}{*}{ 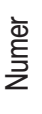 } & Cele priorytetowe & Cele szczegółowe* \\
\hline & \multicolumn{2}{|r|}{ komponent regionalny } \\
\hline 1 & $\begin{array}{l}\text { Rynek Pracy Otwarty } \\
\text { dla Wszystkich }\end{array}$ & $\begin{array}{l}\text { - zwiększenie zasięgu oddziaływania Aktywnej Polityki Rynku Pracy } \\
\text { - zwiększenie poziomu zatrudnienia osób młodych } \\
\text { - zmniejszenie poziomu bezrobocia wśród osób o szczególnie trudnej } \\
\text { - sytuacji na rynku pracy } \\
\text { - zwiększenie poziomu zatrudnienia osób starszych }\end{array}$ \\
\hline 2 & $\begin{array}{l}\text { Promocja integracji } \\
\text { społecznej }\end{array}$ & $\begin{array}{l}\text { - poprawa dostępu do rynku pracy osób zagrożonych wykluczeniem } \\
\text { społecznym }\end{array}$ \\
\hline 3 & $\begin{array}{l}\text { Regionalne kadry } \\
\text { gospodarki }\end{array}$ & - rozwój wykwalifikowanej i zdolnej do adaptacji siły roboczej \\
\hline 4 & $\begin{array}{l}\text { Rozwój wykształcenia } \\
\text { i kompetencji } \\
\text { w regionach }\end{array}$ & $\begin{array}{l}\text { - zmniejszenie nierówności w upowszechnianiu edukacji, szczególnie } \\
\text { pomiędzy obszarami miejskimi i wiejskimi } \\
\text { - zmniejszenie nierówności w jakości usług edukacyjnych, szczególnie } \\
\text { pomiędzy obszarami miejskimi i wiejskimi } \\
\text { - podniesienie atrakcyjności kształcenia zawodowego } \\
\text { - wzmocnienie rozwoju zawodowego i podnoszenia kwalifikacji nauczycieli, } \\
\text { szczególnie na obszarach wiejskich }\end{array}$ \\
\hline 5 & Pomoc techniczna & \\
\hline
\end{tabular}

* W tabeli wyodrębniono tylko te z celów szczegółowych, które bezpośrednio nakierowane są na rozwój kapitału ludzkiego.

Źródło: Program Operacyjny Kapitał Ludzki, Warszawa 2007, s. 161-206, cyt. za: Tkaczyński, Willa, Świstak, 2008, s. 498-499.

środków na cele związane z realizacją Strategii Lizbońskiej, znajduje to odzwierciedlenie w zapisach SPO KL, gdzie wskaźnik ten wynosi 83\% łącznej alokacji środków (Tkaczyński, Willa, Świstak, 2008).

Program składa się z dwóch komponentów: centralnego i regionalnego. U podstaw tego podziału leży przekonanie o wyższej efektywności programów wdrażanych regionalnie, o możliwościach zindywidualizowanego doboru instrumentów i metod.

W ramach komponentu centralnego środki przeznaczone zostaną przede wszystkim na działania o charakterze instytucjonalnym (efektywność struktur i systemów instytucjonalnych), w ramach komponentu regionalnego środki przeznaczone zostaną głównie na wsparcie osób i grup społecznych. 


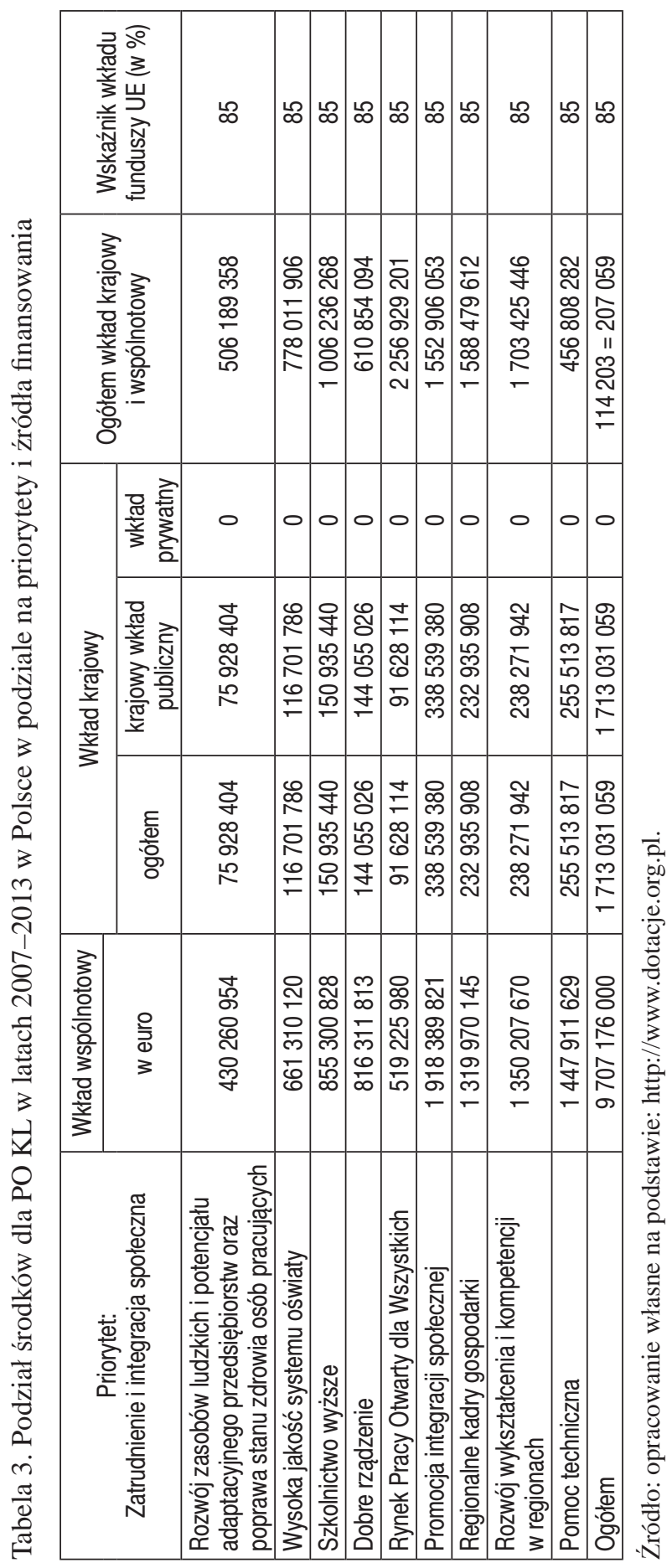




\section{PODSUMOWANIE}

Pomoc oferowana przez UE w ramach polityki strukturalnej przyczyni się z pewnością do rozwoju zasobów ludzkich w Polsce. Będzie to w dużej mierze zależało od zdolności gospodarki do jej absorbcji ${ }^{3}$.

Fundusze unijne nie stanowią jednak remedium na kondycję polskiej gospodarki. Ocena skutków świadczonej pomocy jest niejednoznaczna. W niektórych scenariuszach ${ }^{4}$ przewiduje się, iż wpłynie ona w niewielkim stopniu na dynamikę PKB (do roku 2013 wzrost PKB w scenariuszu z udziałem ZPO KL będzie wyższy aniżeli bez jego udziału o około 1,56 pkt proc.) i sytuację na rynku pracy (obniżenie poziomu bezrobocia jedynie o ok. 1 pkt proc.). Wskutek implementacji PO KL o ok. 120 tys. zwiększy się liczba nowych miejsc pracy. Istotny natomiast pozostanie wpływ wdrożenia Programu na wydajność pracy. Jest to niewątpliwy skutek doskonalenia kapitału ludzkiego leżący u jego podstaw.

\section{LITERATURA}

Auleytner J. (1997), Polityka społeczna - teoria a praktyka, Warszawa.

Grewiński M. (2003), Przygotowania Polski do absorpcji funduszy strukturalnych Unii Europejskiej, Instytut Europejski, Warszawa.

Grewiński M. (red.) (2006), Europejski Fundusz Społeczny i Europejski Fundusz Rozwoju

Regionalnego. Od teorii do praktyki, Dom Wydawniczy Elipsa, Warszawa, 66-68. Grewiński M., Malinowski K. (2003), Europejski Fundusz Socjalny i rynek pracy w Unii Europejskiej, Warszawa.

Kubisz M. (2001), Europejski Fundusz Spoleczny - szansa i wyzwania dla Polski, Warszawa, 10-11.

Rozporządzenie 1784/1999/WE Parlamentu Europejskiego i Rady z dnia 12 lipca 1999 r.,

Dz. Urz. Serii L, nr 213.

Sobotka K. (2001), Zasady korzystania z funduszy europejskich na rzecz rozwoju zasobów ludzkich, Instytut Europejski, Łódź, 32-32.

Tkaczyński W., Willa R., Świstak M. (2008), Fundusze Unii Europejskiej 2007-2013.

Cele - działania - środki, Wyd. Uniwersytetu Jagiellońskiego, Kraków.

http://www.europarl.europa.eu.

http://www.funduszestrukturalne.gov.pl.

3 Według raportu firmy konsultingowej Blomeyer and Sanz prowadzącej badania na zamówienie Komisji Kontroli Budżetowej Parlamentu Europejskiego na koniec 2007 r.: 52,64\%. Dla porównania: na Litwie 35,78\%, Łotwie i Estonii 60,09\%. W tym samym roku w Polsce w ramach EFS wykorzystano 27,2\%, na Litwie 36,91\%, Łotwie 46,13\%, Estonii 43,37\%. Por. http://www.europarl.europa.eu.

${ }^{4}$ Ocena wpływu Narodowych Strategicznych Ram Odniesienia i Programów Operacyjnych na lata 2007-2013 na polską gospodarkę za pomocą modelu Hermin, http://www.funduszestrukturalne.gov.pl. 


\section{THE ROLE OF THE EUROPEAN SOCIAL FUND IN THE HUMAN RESOURCES DEVELOPMENT}

A b stract: The European Social Fund was created in 1957 on the basis of article 23, Treaty of EEC. It was the first structural fund of the European Commonwealth. The Fund works by creating the mechanisms to support the development of labour markets, which in turn, support the realization of the European Strategy of Employment. The article defines the role of the European Social Fund as the supporting instrument for the development of human capital in Poland. It outlines the major activities of the program and the proper priorities for the fund. It also contains empirical data relating to the allocation of funds used by the Human Capital Operational Programme to various priorities, as well as the funding sources, for the period from 2007 till 2013.

Ke y w or d s: European Social Fund, European Strategy of the Employment, human capital, human resources development. 